\title{
Article
}

\section{Suitability of the Available Options About Computer Applications to Record the Initial Assessment of the Nutritional Care Process: A Pilot Study in Spanish Software}

\author{
Mario Navarro Gomis ${ }^{1}$, José Miguel Martínez-Sanz ${ }^{2, *}{ }^{\circledR}$, Isabel Sospedra ${ }^{2}\left(\mathbb{C}\right.$ and María Teresa Romá-Ferri ${ }^{2}(1)$ \\ 1 Faculty of Health Sciences, University of Alicante, 03690 San Vicente del Raspeig, Alicante, Spain; \\ marionavarrogomis10@gmail.com \\ 2 Department of Nursing, Faculty of Health Sciences, University of Alicante, 03690 San Vicente del Raspeig, \\ Alicante, Spain; isospedra@ua.es (I.S.); mtr.ferri@ua.es (M.T.R.-F.) \\ * Correspondence: josemiguel.ms@ua.es; Tel.: +34-965-909-806
}

\section{check for}

updates

Citation: Gomis, M.N.; Martínez-Sanz, J.M.; Sospedra, I.; Romá-Ferri, M.T. Suitability of the Available Options About Computer Applications to Record the Initial Assessment of the Nutritional Care Process: A Pilot Study in Spanish Software. Appl. Sci. 2021, 11, 534. https://doi.org/10.3390/app11020 534

Received: 10 November 2020

Accepted: 5 January 2021

Published: 7 January 2021

Publisher's Note: MDPI stays neutral with regard to jurisdictional clai$\mathrm{ms}$ in published maps and institutional affiliations.

Copyright: (C) 2021 by the authors. Licensee MDPI, Basel, Switzerland. This article is an open access article distributed under the terms and conditions of the Creative Commons Attribution (CC BY) license (https:// creativecommons.org/licenses/by/ $4.0 /)$.

\begin{abstract}
Background: Nutritional software applications are tools for professional care. These applications allow the management of relevant information, facilitating and speeding up the diet treatment, and are designed for a general population with potential nutritional problems. The aim to establish the degree to which existing nutritional software in Spanish covers the nutritional assessment aspects that dietitian needs to manage the nutritional care process (NCP). Methods: A descriptive-comparative study of four open-access and/or trial version nutritional software applications was performed, focusing on the informational content that must be recorded by the dietitian when performing a nutritional assessment. The usability and usefulness of the NCP were analyzed by means of a dichotomous scale (yes/no) and a five-level Likert scale (very complete, complete, basic, poor, very poor). Data collection was carried out from December 2018 to April 2019. Results: The software applications collect personal data in a very intuitive way, and with respect to the nutritional assessment, the applications generally comply with the collection of the basic information necessary for subsequent dietetic planning and are complete in the coinciding items, especially in Dietopro ${ }^{\circledR}$ (Valencia, Spain) and Easydiet ${ }^{\circledR}$ (Navarra, Spain). Conclusion: The applications are generally adapted to the ADA and BDA specifications, though the information is dispersed and without a sequential order for professionals.
\end{abstract}

Keywords: software; nutrition care process; nutrition assessment; food and nutrition

\section{Introduction}

The vision of nutritional care has evolved over the years, from a purely biological orientation to the present day, when it is considered a preventive health treatment that encompasses a multifactorial context that influences the individual [1,2]. However, a key aspect of establishing a pertinent nutritional diagnosis and its timely treatment is found in the application of the nutritional care process (NCP) by the dietitians [3]. This process was standardized by the American Association of Dietitians, currently the American Academy of Nutrition and Dietetics (ADA), in 2003 so that all professionals in this field had a common frame of reference on how to perform their healthcare [3]. The NCP was also described in the UK, for the first time, in the curriculum learning outcomes published by the Board of Dietitians in 2000 and in the Standards of Competence established by the Health and Care Professions Council (HCPC) since 2007 [4]. In both references, the process is constituted of four well-differentiated phases, arranged sequentially and which feed into each other: nutritional assessment, diagnosis, intervention (although the British Dietetic Association, BDA, subdivides it into two stages: strategy and implementation), and nutritional monitoring or evaluation $[3,4]$. This frame of reference must be visible in the care records used by the dietitian [5]. Records are an essential element of intra- 
and inter-professional communication, facilitating the documentation of the professional contribution to the health of the person-population and contributing, as a source of primary information, to research and the training of new professionals $[3,6]$.

In recent years, advances in information and communication technologies (ICT) have become relevant in the field of health in general and, specifically, in the design of records of healthcare, as opposed to paper-based data collection [6]. Computerized registries have facilitated simultaneous and continuous multidisciplinary care, using a single clinical registry, although the different professionals do not coincide in place and time [7]. Immediate access to relevant patient data makes the process of the evaluation of results after dietarynutritional treatment more effective [3,8-10]. Likewise, the evolution of ICT has led to the development of software applications aimed at direct professional-patient communication outside the outpatient setting [5]. These complementary tools facilitate a dynamic interaction in the follow-up, with reduced time intervals, oriented to a response-stimulation in order to achieve greater adherence to the therapeutic indications; for example, using a mobile device to access an application to self-prepare or track the weekly diet plan [11]. This is also practical for dietitians, as they can more objectively individualize the treatment and take advantage of face-to-face, in-office interaction to focus on the most critical aspects of compliance [10].

Although computer applications improve the analysis of nutritional data, the simple accumulation of data does not per se lead to better care [8]. The quality of the nutritional assistance is related, as observed in the Improvement of Education and Competencies project in Dietetics (IMPECD) [9], with the collection of data in the initial assessment, the selective follow-up adjusted to each circumstance, the evaluation of results based on the established objectives and according to the planned interventions, and the report of the developed care. It must not be forgotten that in each phase of the nutritional care process (NCP), it is essential to select and apply the appropriate indicators to carry out a good nutritional study [9]. Therefore, these essential blocks of information should be present in any electronic record developed to document the care provided by dietitians. The electronic records act as a useful tool for the professional. The software allows the collection of a large amount of information (data of food and nutrition-related history, anthropometric measurements, biochemical data, medical tests). This information, as Kight et al. point out, can be included in structured data formats (more precise and concrete, in a fixed field, through can include checkboxes, dropdown lists, and radio buttons) and in unstructured data formats (in a field like a free narrative text). This essential information is integrated, and it can be easily retrieved for reports, flowsheets, or graphs [12], which facilitates the analysis and comparison of patients' dietary records, thus streamlining the care process, reducing possible errors in the calculation of nutritional needs, and facilitating the updating of data [13].

However, these electronic registers are pre-established templates, a set of fields that is, the general register of a database-which respond to the prevailing needs of the general population and follow generic guidelines [14]. Therefore, these aspects must be placed in the context of the current offer. However, Spain and some countries as Belgium or Slovenia do not have validated methods to guarantee nutritional attention based on scientific evidence, as it happens in other European countries as the UK and also in the United States or Canada [4,15-17]. Those countries have the NCP and a standardized language (SL). This underlines the importance of carrying out a study about how these software applications can help us to develop a methodology and a common SL to work in concordance with other dietitians around the world [18].

The aim of this work is to establish the degree to which existing nutritional software applications in Spanish cover the nutritional assessment aspects that dietitians need to manage the nutritional care process for users and/or patients, as well as the usefulness and the usability of the software. 


\section{Materials and Methods}

\subsection{Study Type and Study Population}

A descriptive comparative study of the available nutritional software in Spanish (Dial ${ }^{\circledR}$ (Madrid, Spain), Menu Planner ${ }^{\circledR}$ (Barcelona, Spain), Diet Creator ${ }^{\circledR}$ (Barcelona, Spain), ODIMET ${ }^{\circledR}$ (Santiago de Compostela, Spain), Dietopro ${ }^{\circledR}$ (Valencia, Spain), Easydiet ${ }^{\circledR}$ (Navarra, Spain), Nutrium ${ }^{\circledR}$ (Braga, Portugal), and Equilibra ${ }^{\circledR}$ (Quito, Ecuador) was carried out. Those that met the criteria of open access and/or trial version formed the study sample (Dietopro $^{\circledR}$, Easydiet $^{\circledR}$, Nutrium $^{\circledR}$, and Equilibra ${ }^{\circledR}$ ).

\subsection{Study Variables}

The definitions of the conceptual and operational variables that delimited this study were:

- NCP registration: In this case and based on both definitions of the medical subject headings [19] and the law 41/2002 [13], it was considered that the NCP records are the documentary support that allows collection of all the data and information that are necessary, and mandatory for health professionals, to record the professional actions carried out in each phase of the care process according to the ADA and BDA: nutritional assessment, diagnosis, intervention, and nutritional monitoring or evaluation. This record must meet certain requirements, such as those stated in the Pablo-Rocano study [20]: they must be "complete, timely and pertinent, the information must be clear, concise and orderly to allow efficient analysis. These conditions were evaluated using a template (Appendix A).

- Nutritional assessment: Nutritional assessment is the first phase of the NCP $[3,21]$. Within this system, its purpose is to obtain all the relevant information needed to identify the nutritional factors that affect the nutritional and health status of the patient, as well as the possible causes of deterioration [22]. Nutritional assessment was operationally defined, based on the blocks highlighted by the ADA $[3,21]$, specifically by the presence of predetermined items (structured data formats) or spaces (unstructured data formats) to record data and information concerning the: reason for the consultation, family history, personal history, food supplements, sports supplements, gynecological aspects, physical examination, clinical data (medical and biochemical), anthropometry, dietary history, social habits, records, physical activity (Appendix A).

- Software utility and usability: The ISO 25010 standard defines usability as the "ability of the software product to be understood, learned, used and attractive to the user, when used under certain conditions" [23], while utility is the feature through which the set of components of a system is organized to provide efficient solutions to business needs from the perspective of computing. Taking these definitions as a reference, the utility of the software for clinical practice was assessed in this pilot study using a Likert scale (defined in the Data collection instrument section) and the usability was assessed through the subjective opinion of two evaluators after having studied the different software.

\subsection{Data Collection Instrument}

A data collection form was developed using the Office ${ }^{\circledR}$ Excel datasheet; it included the operational variables of the initial nutritional assessment (Appendix A). This instrument was divided into two blocks: (1) data necessary for the identification of the patient/client within the software and (2) data that include the initial nutritional assessment. To measure the utility and usability of the nutritional assessment, two scales were applied. First, a dichotomous scale was used to check whether the items to be studied were present or not. Second, a Likert scale with five levels of assessment was applied to determine the degree to which the variables represented in the software facilitated the recording of the precise information for the dietetic-nutritional care of athletes. The scale established is shown in Table 1; each level of the scale was defined to maintain a homogeneous criterion for data collection. 
Table 1. Levels and requirements to apply a Likert scale.

\begin{tabular}{cc}
\hline Level & Valuation Criteria \\
\hline Complete & The indicator appears with most of the essential data \\
Bearly complete & Basic indicators appear \\
Basic & Only the item or a text box appears \\
Poor & The selection criteria are limited, and the information cannot be extended or modified \\
Very poor & The item is missing \\
\hline
\end{tabular}

\subsection{Data Collection Procedure}

The data were collected by two evaluators, using a form, from December 2018 to June 2019. A dummy patient was created within the different software when registering the client in the first consultation. The items were divided into two well-differentiated sections: in the first, personal data were verified, and in the second, a nutritional assessment was performed. Data were collected for the coincident variables that, as a minimum, had to coincide in two of the analyzed software. The nomenclature used to name the different software analyzed was Dietopro ${ }^{\circledR}(\mathrm{Di})$, Easydiet ${ }^{\circledR}(\mathrm{Ea})$, Nutrium $^{\circledR}(\mathrm{Nu})$, and Equilibra $^{\circledR}(\mathrm{Eq})$.

\subsection{Analysis of Data}

A qualitative comparison of the studied software was developed by a group of four expert evaluators to determine if they included the information blocks required by the ADA NCP. The items described in Appendix A were verified as coincident in order to make a subsequent comparison of the computer software.

\section{Results}

The different software applications provide a complete and intuitive template for recording a patient's personal data, except for the Equilibra ${ }^{\circledR}$ software, which has a very poor record for such data. In the nutritional assessment section, when comparing the items provided by the software with respect to the information blocks established by the ADA, the biochemical data in Easydiet ${ }^{\circledR}$ and Equilibra ${ }^{\circledR}$ stand out as a basic, being poor or very poor in the other software. Regarding the anthropometric data, the items provided by Easydiet $^{\circledR}$ and Dietopro ${ }^{\circledR}$ give a very complete coverage regarding the indication of the ADA. In this nutritional assessment section, the physical activity items in the Easydiet ${ }^{\circledR}$ software also stand out, with a very complete coverage (Table 2).

Globally, and according to the evaluation criteria, the software includes the following information: Dietopro ${ }^{\circledR}$ had a coincidence $>70 \%$ in the informative blocks of previous pathologies, anthropometric data, and habit records. In Easydiet ${ }^{\circledR}$, a similar coincidence was found for the family history, previous pathologies, and physical activity sections. In contrast, Nutrium ${ }^{\circledR}$ and Equilibra ${ }^{\circledR}$ did not cover these informative blocks. The program with the most matching items was Easydiet ${ }^{\circledR}$, and the one with the most non-matching items was Equilibra ${ }^{\circledR}$. Regarding the physical activity and habit records, Easydiet ${ }^{\circledR}$ had more matching items in these sections than the rest of the software applications. These results can be seen in Table 3 .

When registering the patient, Dietopro ${ }^{\circledR}$ — as opposed to the rest of the software applications, which request only personal data-incorporates the possibility of assigning a photograph to its electronic file so that the dietitian can quickly recognize the client by their personal photograph. In addition, Dietopro ${ }^{\circledR}$ includes a photographic assessment option more focused on the nutritional monitoring part, where-through a series of photographs-the variation in body composition during the nutritional treatment can be assessed. Any private data of the registered user must comply with the regulation of general data protection regulation. Dietopro ${ }^{\circledR}$ is the only software application that includes an express written consent that must be filled and signed by the customer before the nutritional treatment. With the other software applications described, the professional must guarantee the protection of the data to comply with the law. 
Table 2. Coverage of the coinciding variables of nutritional assessment of the records of the software analysed with respect to the ADA indications.

\begin{tabular}{|c|c|c|c|c|c|}
\hline & Complete & Nearly Complete & Basic & Poor & Very Poor \\
\hline Reason for query & & & $\mathrm{Ea}-\mathrm{Nu}$ & Di & $\mathrm{Eq}$ \\
\hline Family background & Ea & & $\mathrm{Nu}$ & $\mathrm{Di}$ & $\mathrm{Eq}$ \\
\hline Obesity & Ea-Di & & & & $\mathrm{Nu}-\mathrm{Eq}$ \\
\hline Personal background & & & $\mathrm{Ea}-\mathrm{Nu}$ & & DI-Eq \\
\hline Current diseases & $\mathrm{Ea}$ & & DI-Nu & $\mathrm{Eq}$ & \\
\hline Other diseases & Ea & & DI-Un & & $\mathrm{Eq}$ \\
\hline Pharmacology & & & Di-Un & & Ea-Eq \\
\hline Gynaecologic aspects & Ea & & Di & & $\mathrm{Nu}-\mathrm{Eq}$ \\
\hline Current pregnancy & Ea & & $\mathrm{Di}-\mathrm{Nu}$ & & $\mathrm{Eq}$ \\
\hline Clinical data & Ea & & & Di-Un & Eq \\
\hline Medical report & Ea & & & $\mathrm{Di}-\mathrm{Nu}-\mathrm{Eq}$ & \\
\hline Biochemistry & & & Ea-Eq & Di & $\mathrm{Nu}$ \\
\hline Total cholesterol & & & Ea-Eq & & Di \\
\hline Hdl & & & $\mathrm{Ea}$ & $\mathrm{Nu}$ & Di-Eq \\
\hline Ldl & & & $\mathrm{Ea}$ & $\mathrm{Nu}$ & Di-Eq \\
\hline Triglycerides & & & Ea & $\mathrm{Nu}$ & Di-Eq \\
\hline Anthropometric data & Di-Ea & & & $\mathrm{Nu}$ & $\mathrm{Eq}$ \\
\hline Weight $(\mathrm{kg})$ & Di-Ea & & & & $\mathrm{Nu}-\mathrm{Eq}$ \\
\hline Stature $(\mathrm{cm})$ & $\mathrm{Di}-\mathrm{Ea}-\mathrm{Nu}$ & & & & $\mathrm{Eq}$ \\
\hline Mid-upper arm circumference (cm) & $\mathrm{Di}-\mathrm{Ea}-\mathrm{Nu}$ & & & & $\mathrm{Eq}$ \\
\hline Mid-arm muscle circumference $(\mathrm{cm})$ & Di-Ea & & & & $\mathrm{Nu}-\mathrm{Eq}$ \\
\hline Forearm circumference $(\mathrm{cm})$ & $\mathrm{Di}-\mathrm{Ea}$ & & $\mathrm{Eq}$ & & $\mathrm{Nu}$ \\
\hline Waist circumference $(\mathrm{cm})$ & $\mathrm{Di}-\mathrm{Ea}$ & & $\mathrm{Eq}$ & & $\mathrm{Nu}$ \\
\hline Hip circumference $(\mathrm{cm})$ & $\mathrm{Di}-\mathrm{Ea}-\mathrm{Nu}$ & & & & $\mathrm{Eq}$ \\
\hline Subscapular skinfold (mm) & $\mathrm{Di}-\mathrm{Ea}-\mathrm{Nu}$ & & & & $\mathrm{Eq}$ \\
\hline Chest skinfold (mm) & $\mathrm{Di}-\mathrm{Ea}-\mathrm{Nu}$ & & & & $\mathrm{Eq}$ \\
\hline Auxiliary skinfold (mm) & $\mathrm{Di}-\mathrm{Ea}-\mathrm{Nu}$ & & & & $\mathrm{Eq}$ \\
\hline Suprailiac skinfold (mm) & $\mathrm{Di}-\mathrm{Ea}-\mathrm{Nu}$ & & & & $\mathrm{Eq}$ \\
\hline Abdominal skinfold (mm) & $\mathrm{Di}-\mathrm{Ea}-\mathrm{Nu}$ & & & & Eq \\
\hline Mid-thigh skinfold (mm) & $\mathrm{Di}-\mathrm{Ea}-\mathrm{Nu}$ & & & & $\mathrm{Eq}$ \\
\hline Comments & $\mathrm{Di}-\mathrm{Ea}-\mathrm{Nu}$ & & & & Eq \\
\hline Blood pressure & $\mathrm{Di}-\mathrm{Ea}-\mathrm{Nu}$ & & & & $\mathrm{Eq}$ \\
\hline \multicolumn{6}{|l|}{ Dietetic history and social habits } \\
\hline Allergy & & & $\mathrm{Di}-\mathrm{Ea}-\mathrm{Nu}$ & & $\mathrm{Eq}$ \\
\hline Intolerance & & & Di-Ea-Nu & & $\mathrm{Eq}$ \\
\hline$\overline{\text { Snacking }}$ & Ea & & & Di & $\mathrm{Nu}-\mathrm{Eq}$ \\
\hline Registrations & & & $\mathrm{B}-\mathrm{C}$ & & Di-Eq \\
\hline Consumption & Di & Ea & & $\mathrm{Nu}-\mathrm{Eq}$ & \\
\hline Alcohol & $\mathrm{Di}-\mathrm{Ea}$ & & $\mathrm{Nu}$ & & $\mathrm{Eq}$ \\
\hline Tobacco & Di & & $\mathrm{Nu}$ & $\mathrm{Eq}$ & $\mathrm{Ea}$ \\
\hline \multicolumn{6}{|l|}{ Physical activity } \\
\hline Intensity & Di-Ea & & & & $\mathrm{Nu}-\mathrm{Eq}$ \\
\hline Type & $\mathrm{Ea}$ & & & & Di-Nu-Eq \\
\hline Frequency & $\mathrm{Ea}$ & & Di & & $\mathrm{Nu}-\mathrm{Eq}$ \\
\hline Duration & Ea & & Di & & $\mathrm{Nu}-\mathrm{Eq}$ \\
\hline
\end{tabular}

Di: Dietopro ${ }^{\circledR} ;$ Ea: Easydiet ${ }^{\circledR} ;$ Nu: Nutrium $^{\circledR} ;$ Eq: Equilibra ${ }^{\circledR}$.

Another aspect of these software applications to highlight is the way of entering biochemical data. In Dietopro ${ }^{\circledR}$, the analytical data are scanned, thus obtaining the digitized document, but neither this document nor the way of entering the data can be modified. The only option that this software allows when uploading these data are a text box to leave the observations that the professional considers convenient. While Easydiet ${ }^{\circledR}$ and Nutrium ${ }^{\circledR}$ include, by default, a limited number of biochemical items in a text box format, these items are not expandable or modifiable. Hence, that the user can understand the data, the Easydiet ${ }^{\circledR}$ software provides several downloadable files with templates on the interpretation of biochemical parameters and requests for blood/urine tests. 
Table 3. Assessment of matching and mismatched items.

\begin{tabular}{|c|c|c|c|c|c|c|c|c|c|c|c|c|c|c|c|c|}
\hline & \multicolumn{2}{|c|}{$\begin{array}{l}\text { Nutritional } \\
\text { Assessment }\end{array}$} & \multicolumn{2}{|c|}{$\begin{array}{c}\text { Family } \\
\text { Background }\end{array}$} & \multicolumn{2}{|c|}{ Prior Disease } & \multicolumn{2}{|c|}{$\begin{array}{l}\text { Biochemical } \\
\text { Data }\end{array}$} & \multicolumn{2}{|c|}{$\begin{array}{c}\text { Anthropometric } \\
\text { Data }\end{array}$} & \multicolumn{2}{|c|}{$\begin{array}{c}\text { Dietetic } \\
\text { History and } \\
\text { Social Habits }\end{array}$} & \multicolumn{2}{|c|}{ Register } & \multicolumn{2}{|c|}{$\begin{array}{l}\text { Physical } \\
\text { Activity }\end{array}$} \\
\hline & $\begin{array}{l}\% \\
\text { MI }\end{array}$ & $\begin{array}{c}\% \\
\text { MMI }\end{array}$ & $\begin{array}{l}\% \\
\text { MI }\end{array}$ & $\begin{array}{c}\% \\
\text { MMI }\end{array}$ & $\begin{array}{l}\% \\
\text { MI }\end{array}$ & $\begin{array}{c}\% \\
\text { MMI }\end{array}$ & $\begin{array}{l}\% \\
\text { MI }\end{array}$ & $\begin{array}{c}\% \\
\text { MMI }\end{array}$ & $\begin{array}{l}\% \\
\text { MI }\end{array}$ & $\begin{array}{c}\% \\
\text { MMI }\end{array}$ & $\begin{array}{l}\% \\
\text { MI }\end{array}$ & $\begin{array}{c}\% \\
\text { MMI }\end{array}$ & $\begin{array}{l}\% \\
\text { MI }\end{array}$ & $\begin{array}{c}\% \\
\text { MMI }\end{array}$ & $\begin{array}{l}\% \\
\text { MI }\end{array}$ & $\begin{array}{c}\% \\
\text { MMI }\end{array}$ \\
\hline Di & $\begin{array}{l}67 \% \\
(4)\end{array}$ & $\begin{array}{l}33 \% \\
(2)\end{array}$ & $\begin{array}{l}33 \% \\
(2)\end{array}$ & $\begin{array}{l}67 \% \\
(4)\end{array}$ & $\begin{array}{l}75 \% \\
(6)\end{array}$ & $\begin{array}{l}25 \% \\
(2)\end{array}$ & $\begin{array}{l}2 \% \\
(1)\end{array}$ & $\begin{array}{l}98 \% \\
(46)\end{array}$ & $\begin{array}{c}100 \% \\
(35)\end{array}$ & $\begin{array}{l}0 \% \\
(0)\end{array}$ & $\begin{array}{l}50 \% \\
(10)\end{array}$ & $\begin{array}{l}50 \% \\
(10)\end{array}$ & $\begin{array}{c}25 \% \\
\text { (3) }\end{array}$ & $\begin{array}{c}75 \% \\
(9)\end{array}$ & $\begin{array}{l}43 \% \\
\text { (3) }\end{array}$ & $\begin{array}{c}57 \% \\
(4)\end{array}$ \\
\hline Ea & $\begin{array}{l}33 \% \\
(2)\end{array}$ & $\begin{array}{l}67 \% \\
(4)\end{array}$ & $\begin{array}{l}100 \% \\
(6)\end{array}$ & $\begin{array}{l}0 \% \\
(0)\end{array}$ & $\begin{array}{l}88 \% \\
(7)\end{array}$ & $\begin{array}{l}13 \% \\
(1)\end{array}$ & $\begin{array}{l}19 \% \\
(9)\end{array}$ & $\begin{array}{l}81 \% \\
(26)\end{array}$ & $\begin{array}{l}60 \% \\
(21)\end{array}$ & $\begin{array}{l}40 \% \\
(14)\end{array}$ & $\begin{array}{l}50 \% \\
(10)\end{array}$ & $\begin{array}{l}50 \% \\
(10)\end{array}$ & $\begin{array}{l}58 \% \\
(7)\end{array}$ & $\begin{array}{l}42 \% \\
(5)\end{array}$ & $\begin{array}{c}86 \% \\
(6)\end{array}$ & $\begin{array}{l}14 \% \\
(1)\end{array}$ \\
\hline $\mathrm{Nu}$ & $\begin{array}{c}33 \% \\
(2)\end{array}$ & $\begin{array}{l}67 \% \\
(4)\end{array}$ & $\begin{array}{l}17 \% \\
(1)\end{array}$ & $\begin{array}{l}83 \% \\
(5)\end{array}$ & $\begin{array}{l}50 \% \\
(4)\end{array}$ & $\begin{array}{l}50 \% \\
(4)\end{array}$ & $\begin{array}{l}9 \% \\
(4)\end{array}$ & $\begin{array}{l}91 \% \\
(43)\end{array}$ & $\begin{array}{l}37 \% \\
(13)\end{array}$ & $\begin{array}{l}63 \% \\
(22)\end{array}$ & $\begin{array}{l}15 \% \\
(3)\end{array}$ & $\begin{array}{l}85 \% \\
(17)\end{array}$ & $\begin{array}{l}42 \% \\
(5)\end{array}$ & $\begin{array}{l}58 \% \\
(7)\end{array}$ & $\begin{array}{l}0 \% \\
(0)\end{array}$ & $\begin{array}{c}100 \% \\
(7)\end{array}$ \\
\hline Eq & $\begin{array}{l}0 \% \\
(0)\end{array}$ & $\begin{array}{c}100 \% \\
(6)\end{array}$ & $\begin{array}{l}0 \% \\
(0)\end{array}$ & $\begin{array}{c}100 \% \\
(6)\end{array}$ & $\begin{array}{l}13 \% \\
(1)\end{array}$ & $\begin{array}{l}88 \% \\
(7)\end{array}$ & $\begin{array}{l}13 \% \\
(6)\end{array}$ & $\begin{array}{l}87 \% \\
(41)\end{array}$ & $\begin{array}{l}11 \% \\
(4)\end{array}$ & $\begin{array}{l}89 \% \\
(31)\end{array}$ & $\begin{array}{l}10 \% \\
(2)\end{array}$ & $\begin{array}{l}90 \% \\
(18)\end{array}$ & $\begin{array}{l}17 \% \\
(2)\end{array}$ & $\begin{array}{l}83 \% \\
(10)\end{array}$ & $\begin{array}{l}43 \% \\
(3)\end{array}$ & $\begin{array}{c}57 \% \\
(4)\end{array}$ \\
\hline
\end{tabular}

MI: matching items; MMI: mismatched items; Di: Dietopro ${ }^{\circledR} ;$ Ea: Easydiet $^{\circledR} ;$ Nu: Nutrium $^{\circledR} ;$ Eq: Equilibra $^{\circledR}$.

The most notable item in the section on dietary history and social habits is the record of allergy and intolerance. In case the client did not specify it or mention it to the dietitian, the software applications, except Equilibra ${ }^{\circledR}$, all have a section to enter this information. With reference to the items on dietary records, the only software application that requested information on this subject, through a $24 \mathrm{~h}$ reminder, were Easydiet ${ }^{\circledR}$ and Nutrium ${ }^{\circledR}$.

To compare the software, percentage values were calculated according to the Likert scale applied to the coincident variables that appear in at least two of the software. To avoid redundancy, only the matching items will be referred to. It should be noted that in Dietopro $^{\circledR}, 49 \%$ of the items were very complete, $21 \%$ were basic, and $14 \%$ were poor. In Easydiet $^{\circledR}, 70 \%$ were very complete, $2 \%$ were complete, and $23 \%$ were basic. Regarding Nutrium ${ }^{\circledR}, 26 \%$ were very complete, and $28 \%$ were basic; and in Equilibra ${ }^{\circledR}, 9 \%$ were poor, and $28 \%$ were very poor. Concerning the items that were very complete, the difference between the software with the highest percentage (Easydiet ${ }^{\circledR}$ ) and the software with the next highest percentage (Dietopro ${ }^{\circledR}$ ) was $21 \%$. These results can be seen in Table 4 .

Table 4. Assessment of the matching variables according to Likert scale.

\begin{tabular}{cccccc}
\hline Matching Variables & Complete & Nearly Complete & Basic & Poor & Very Poor \\
\hline $\mathrm{Di}$ & $49 \%(21)$ & $0 \%(0)$ & $21 \%(9)$ & $14 \%(6)$ & $9 \%(4)$ \\
$\mathbf{E a}$ & $70 \%(30)$ & $2 \%(1)$ & $23 \%(10)$ & $0 \%(0)$ & $16 \%(7)$ \\
$\mathrm{Nu}$ & $26 \%(11)$ & $0 \%(0)$ & $28 \%(12)$ & $16 \%(7)$ & $5 \%(2)$ \\
$\mathbf{E q}$ & $2 \%(1)$ & $0 \%(0)$ & $5 \%(2)$ & $9 \%(4)$ & $28 \%(12)$ \\
\hline
\end{tabular}

Di: Dietopro ${ }^{\circledR}$, Ea: $^{\text {Easydiet }}{ }^{\circledR}$, Nu: Nutrium ${ }^{\circledR}$, Eq: Equilibra ${ }^{\circledR}$.

Items that were not mentioned in any of the software for the nutritional assessment were: physical examination; previous pathologies of the patient/client; nutritional supplements; sports supplements; and pharmacology, this latter item only being available in the pro version of Dietopro ${ }^{\circledR}$. Furthermore, none of the software analyzed included the option of modifying or expanding the items during the nutritional assessment.

\section{Discussion}

As we have seen in the previous section, with regard to the compared items, the software applications are complete applications that have the ability to record a large amount of useful information for nutritional assessment. Despite their differences, they include several sections that emphasize the general population, athletes, and people with certain pathologies. It is important to stress that most of them incorporate the option of including biochemical and anthropometric data, which are important for health and for the performance and esthetics of people focused on sport.

The correct collection of data by the dietitian is of great importance-and most of the software studied perform this function correctly by incorporating most of the $70 \%$ of the items indicated by the ADA and BDA in the nutritional assessment phase. In this 
way, during the first consultation with the client/patient, the care they receive is tailored as much as possible to their needs and/or pathologies. Electronic nutrition care process record (ENCPR) makes them more accessible, and they can be used by other professionals who form part of an interdisciplinary team [8].

The pre-established templates, of the general register, in these software applications, ensure that none of the data are lost or forgotten when registering the patient and that the data are stored in such a way that both the quality of the service provided and the accessibility of the data are improved [24]. In relation to the initial assessment of the patient/client, a common characteristic among many templates, they are pre-designed and can be modified to personalize the dietetic-therapeutic treatment; these characteristics were found in all the software analyzed except Equilibra ${ }^{\circledR}[25,26]$.

As an example, Dietopro ${ }^{\circledR}$ incorporates the possibility of a photographic assessment, more focused on the nutritional monitoring part. The perception of body image generates great unease since there is often a desire to achieve certain ideals of beauty. Its inclusion in the ENCPR can be useful for the early detection of risk conducts and behaviors [27]. A poor perception of body image can lead to eating disorders, especially in a vulnerable population such as children and adolescents [28,29]. In addition, the overweight/obese population usually presents problems derived from a lack of self-esteem and, in general, a poor perception regarding their image. The analysis of the image evolution can help to improve patient self-esteem [30].

Regarding biochemical data, all software allows you to enter these data. Facilitation of the collection of these data and their subsequent understanding by the dietitian makes it easier for the dietitian, for example, to be aware of how the patient/client is adapting to the type of training or very demanding sports events in which he/she participates, by following changes in his/her hematological profile [31,32]. For the general population, it is also useful to collect these data since a good previous nutritional status has a great influence on certain pathologies; that is, knowledge of the parameters that could be altered, thus acting as indicators, could help the dietitian to prevent the patient/client from becoming ill by ensuring they follow a correct diet [33].

The anthropometric data required by the software make it easier to know the body composition of the patient through indirect formulas; all these software fewer Equilibra ${ }^{\circledR}$ have in common the items corresponding to the anthropometric data. This information in the ENCPR is not only useful to know the client's body composition promptly but also during the monitoring of the nutritional treatment [34]. The software applications that facilitate the collection of these data allow the calculation, through indirect formulas, of the percentage of fat or muscle mass [35]; specifically, Easydiet ${ }^{\circledR}$ performs these calculations automatically once the requested anthropometric data have been entered. In addition, the data may vary depending on the indirect formulas used, and here is one of the main sources of error since, depending on the equation that it uses, the program will take certain variables and constants so that the results will differ among the software [36]. These data can be used to check whether a certain dietary pattern established by the professional brings the patient/client closer to the desired goals or, on the contrary, has a negative impact on their body composition [37].

The dietary records are the most used tools by the dietitians in practice to estimate the intake of the patient/client. These prospective records consist of the patient writing down, over a specific period of time, the food and beverages he/she consumes [38]. The drawback of these methods is that the diet recorded in this way can present great variability, such that it represents the current diet, but not the usual one, which is the one that will affect the client's well-being [39]. Although these methods have limitations, it is important that the software includes sections to record this information since a correct and adequate intake of nutrients will determine health in both the short and long term [39]. Adjustment of the intake of nutrients is important for the population with certain pathologies—such as hypertensive patients, who require adequate control of the sodium/potassium ratio [40]and for athletes, who must optimize their diets due to their high requirements [41]. 
The items related to physical activity-including the intensity, frequency, and duration of the training - can be applied to elite athletes or the general population of clients who perform regular physical activity. However, only Dietopro ${ }^{\circledR}$ and Easydiet ${ }^{\circledR}$ offer the possibility of a complete register. Knowledge of the physical activity of the patients will allow optimization of the dietary pattern, adapting it to the variables of the training or the phase of competition through which the client is currently passing [42]. These software applications could be more specific at the time of the evaluation by including a section that offers the possibility of automatically calculating the caloric requirements of the sports practice that the client performs by multiplying the time dedicated to the practice by the METs of that activity [43].

Regarding the items that are not found in any of the software applications analyzed and that can contribute to misinformation in the ENCPR, the use of food supplements in the general population or by athletes should be highlighted since they are frequently used [44]; hereafter, this item should be included in the nutritional intervention section, as in the case of Dietopro ${ }^{\circledR}$, and also the consumption by the patient in their usual diet should be registered in order to correctly assess their diet [41,45]. Another negative aspect found was the organization of the information, since it did not comply with the provisions of the ADA and BDA [4,9], due to the fact that the software applications are designed to request the most relevant information required to design a nutritional plan adapted to the needs of the patient. This limits the collection of data by software and means that the spectrum they can cover is scarce, thus delimiting the data collection by the DN; hopefully, this will be solved in the next software updates. Other studies have also found problems in nutritional applications since no application capable of adapting to a specific need was found, or there is the fragmentation of the data that makes it necessary to use several applications to have a complete record and thus a correct NCR. Furthermore, the management of this information by the dietitian is necessary so that the health of the patient/client is not affected by inappropriate use without supervision $[11,46]$.

Finally, this research has methodological limitations: since the sample is not significant, and only Spanish software applications were evaluated, these results cannot be extrapolated to the rest of the computer programs available. Another limitation is the analysis and qualitative approach to the study, based on the evaluator's expertise, which makes a deep quantitative analysis difficult. As a positive note, although the present work is a pilot study, it is one of the first research that provides a knowledge base for professionals in the field, collecting together some of the available information about nutritional software intended for use in academic training, research, and for clinical practice.

\section{Conclusions}

The use of nutritional software during the NCR facilitates this process for dietitians. The determined structure of these programs allows them to collect information quickly, concisely, and accurately while allowing individualization of future nutritional intervention.

For the appropriate application of these software applications to the nutritional assessment of sporting clients, it would be necessary to expand the interview items dedicated to physical activity, making it possible for the dietitian to gather more information about training or competition and their nutritional planning.

At a general level, Dietopro ${ }^{\circledR}$ and Easydiet ${ }^{\circledR}$ allow the collection of the basic information necessary, according to the ADA and BDA, to carry out a correct nutritional assessment.

More studies are required in this field as the research into, and development of these software applications continue to evolve. In addition, as there are currently open access applications that are available to any individual, new legislation that controls the use of and access to these programs is of great importance.

It is necessary to emphasize the need to standardize and regulate the methodology and language of the NCP to facilitate the transfer of practical knowledge between professionals of the same sector. 
Author Contributions: J.M.M.-S., M.T.R.-F. and I.S. designed the study and reviewed and supervised the study; M.N.G. data collection; M.N.G., I.S. and J.M.M.-S. interpreted the data; J.M.M.-S., M.T.R.-F. and M.N.G. they wrote the manuscript; J.M.M.-S., M.T.R.-F. and I.S. they reviewed and edited the manuscript. All authors have read and agreed to the published version of the manuscript.

Funding: The authors declare that they have had no source of funding.

Institutional Review Board Statement: Not applicable.

Informed Consent Statement: Not applicable.

Data Availability Statement: The data presented in this study are available in Appendix A. The data presented in this study are available on request from the corresponding author.

Acknowledgments: We are grateful to David Walker and Mario Fon (native English speakers) for their review of the English grammar and style of the current report.

Conflicts of Interest: The authors state that there is no conflict of interest. J.M.M.-S. belongs to the Editorial Board for this Special Issue in Applied Sciences and declares that he had no role in the peer-review process of the manuscript.

\section{Abbreviations}

$\begin{array}{ll}\text { ADA } & \text { American Academy of Nutrition and Dietetics } \\ \text { BDA } & \text { British Dietetic Association } \\ \text { CSD } & \text { Higher Sports Council } \\ \text { ENCPR } & \text { Electronic Nutrition Care Process Record } \\ \text { IMPECD } & \text { Improvement of Education and Competencies in Dietetics } \\ \text { NCP } & \text { Nutritional care process } \\ \text { SL } & \text { Standardized language } \\ \text { TIC } & \text { Information and communication technologies }\end{array}$

\section{Appendix A. Variables Analyzed by the Different Nutritional Software}

The analyzed variables from the different software were divided into two large groups: the first one comprised the data referring to the registration of personal details. The second grouped the items referring to the nutritional clinical history together. This second group included seven sections: nutritional assessment, clinical data, dietary history, social habits, registration, physical activity, and other instruments. To facilitate the understanding of which items are in a certain group, they were ordered by lists.

Table A1. Variables Analyzed by the Different Nutritional Software.

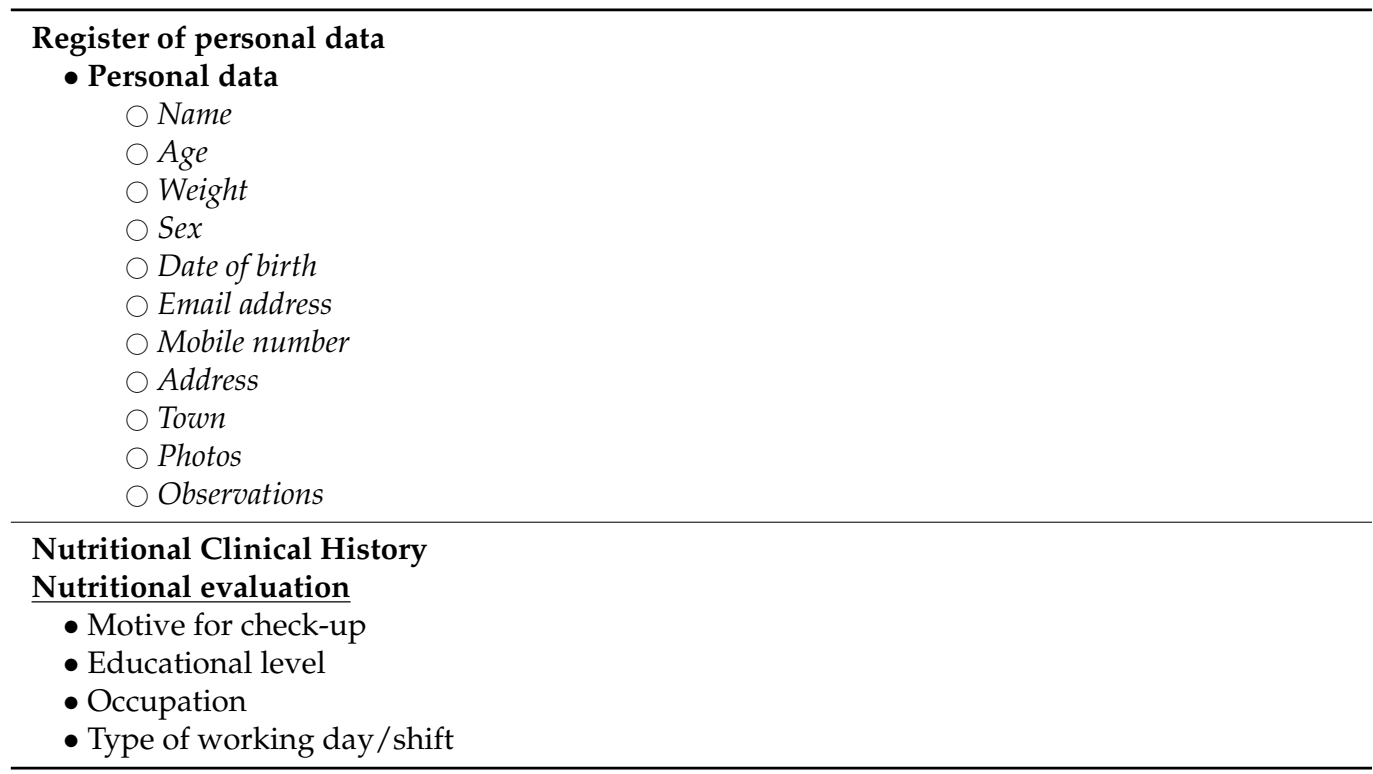


Table A1. Cont.

- Motivation/Degree of support

- Family health history

$\bigcirc$ Obesity

Diabetes

Hypertension

$\bigcirc$ Cancer

$\bigcirc$ Hypercholesterolemia

- Personal medical history

- Previous pathologies $\bigcirc$ Surgery

- Current pathologies

$\bigcirc$ Diarrhea

Constipation

$\bigcirc$ Gastric ulcers

$\bigcirc$ Dental

$\bigcirc$ Other pathologies

- Food supplements

$\bigcirc$ Amount

$\bigcirc$ Frequency

- Sports supplements

$\bigcirc$ Amount

Frequency

$\bigcirc$ Form

- Pharmacological drugs

$\bigcirc$ Brand

$\bigcirc$ Dose

Duration

$\bigcirc$ Drug-nutrient interaction

- Gynecological aspects

$\bigcirc$ Current pregnancy

Lactation (lactating mother)

Oral contraceptives

Brand

Dose

$\bigcirc$ Menopause

$\bigcirc$ Hormone replacement therapy (HRT)

- Physical examination
$\bigcirc$ Nails
$\bigcirc$ Skin
$\bigcirc$ Hair
$\bigcirc$ Eyes

Clinical data

- Medical data

$\bigcirc$ Arterial pressure

$\bigcirc$ Biochemistry

- Hematological data

- Hematology and red blood parameters

$\bigcirc$ Red blood cells count

$\bigcirc$ Hemoglobin

$\bigcirc$ Hematocrits

Corpuscular volume

$\bigcirc$ Reticulocytes

- Hematology and white blood parameters

$\bigcirc$ Leucocytes

$\bigcirc$ Lymphocytes

$\bigcirc$ Neutrophils

$\bigcirc$ Eosinophils

- Other biochemical parameters

- Hormones

$\bigcirc$ Testosterone 
Table A1. Cont.

$\bigcirc$ Cortisol

Testosterone/cortisol index

$\checkmark$ Catecholamines

- Visceral protein behavior
$\bigcirc$ Prealbumin
$\bigcirc$ Retinol-protein
$\bigcirc$ Transferrin
Albumin

- Protein metabolism
$\bigcirc$ Total protein
$\bigcirc$ Amino acids
$\bigcirc$ Tyrosine
3 methyl-histidine
Branched amino acids
$\bigcirc$ Tryptophan
$\bigcirc$ Alanine

- Blood lipids

$\bigcirc$ Total cholesterol

$\circ$ HDL

$\bigcirc$ LDL

$\bigcirc$ Triglycerides

- Carbohydrates metabolism

$$
\text { Glycemia }
$$

- Plasmatic ions
$\bigcirc \mathrm{Na}$
$\mathrm{OK}$
$\bigcirc \mathrm{Mg}$
$\bigcirc \mathrm{Ca}$

- Iron metabolism

Serum iron

$\bigcirc$ Ferritin

$\bigcirc$ Transferrin

- Anthropometric data

$\bigcirc$ Informed consent

Weight $(\mathrm{kg})$

$\bigcirc$ Stature $(\mathrm{cm})$

Biacromial breadth $(\mathrm{cm})^{*}$

Transverse diameter of the thorax $(\mathrm{cm})^{*}$

$\bigcirc$ Antero-posterior chest depth $(\mathrm{cm})^{*}$

$\bigcirc$ Biiliocristal breadth $(\mathrm{cm})^{*}$

Humerus breadth $(\mathrm{cm})$

Bi-styloid breadth $(\mathrm{cm})$

Femur breadth $(\mathrm{cm})$

Bimalleolar breadth $(\mathrm{cm})$

Arm girth relaxed $(\mathrm{cm})$

Arm girth flexed and tensed $(\mathrm{cm})$

Forearm girth $(\mathrm{cm})$

Wrist girth $(\mathrm{cm})$

Neck girth $(\mathrm{cm})$

Waist girth $(\mathrm{cm})$

$\bigcirc$ Average abdominal girth $(\mathrm{cm})$ (only obese individuals)

$\bigcirc$ Hips girth $(\mathrm{cm})$

Thigh $1 \mathrm{~cm}$ gluteal girth $(\mathrm{cm})$

$\bigcirc$ Thigh girth $(\mathrm{cm})$

$\bigcirc$ Calf girth $(\mathrm{cm})$

$\bigcirc$ Ankle girth $(\mathrm{cm})$

$\bigcirc$ Triceps skinfold (mm)

Subscapular skinfold (mm)

Biceps skinfold (mm)

$\bigcirc$ Pectoral skinfold (mm) 
Table A1. Cont.

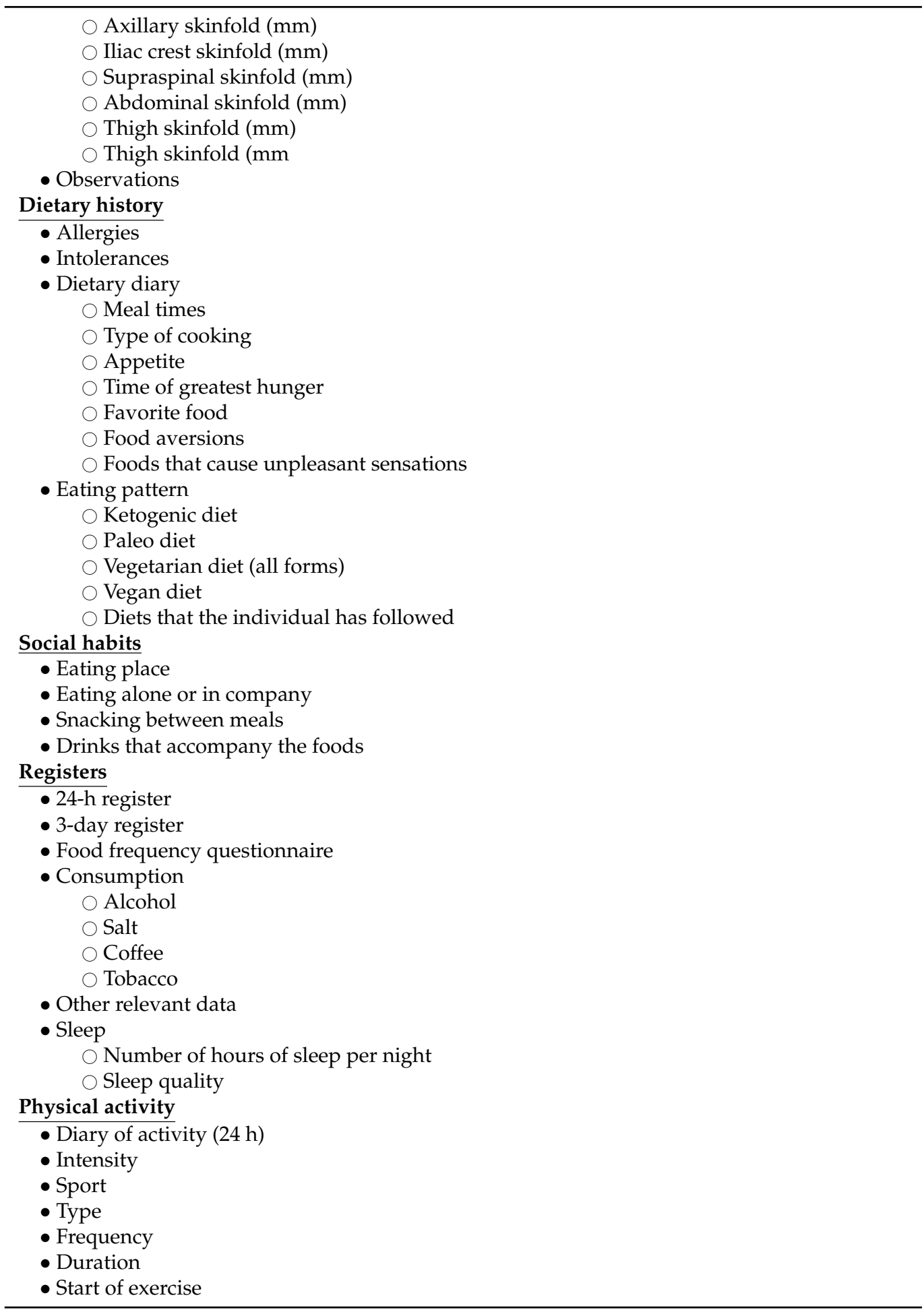

\section{References}

1. Macias, A.I.; Quintero, M.L.; Camacho, E.J.; Sánchez, J.M. La tridimensionalidad del concepto de nutrición: Su relación con la educación para la salud. Rev. Chil. Nutr. 2009, 36, 1129-1135. [CrossRef]

2. Cannon, G.; Leitzmann, C. The New Nutrition Science Project. Public Health Nutr. 2005, 8, 673-694. [CrossRef] [PubMed]

3. Lacey, K.; Pritchett, E. Nutrition Care Process and Model: ADA Adopts Road Map to Quality Care and Outcomes Management. J. Am. Diet. Assoc. 2003, 103, 1061-1072. [CrossRef] 
4. BDA Model and Process for Nutrition and Dietetic Practice. Available online: https://www.bda.uk.com/practice-andeducation/nutrition-and-dietetic-practice/professional-guidance/model-and-process-for-dietetic-practice.html (accessed on 27 December 2020).

5. Chui, T.-K.; Proaño, G.V.; Raynor, H.A.; Papoutsakis, C. A Nutrition Care Process Audit of the National Quality Improvement Dataset: Supporting the Improvement of Data Quality Using the ANDHII Platform. J. Acad. Nutr. Diet. 2019, 120, 1238-1248.E1. [CrossRef]

6. Rossi, M.; Campbell, K.L.; Ferguson, M. Implementation of the Nutrition Care Process and International Dietetics and Nutrition Terminology in a Single-Center Hemodialysis Unit: Comparing Paper vs Electronic Records. J. Acad. Nutr. Diet. 2014, 114, 124-130. [CrossRef]

7. Olmos, M.A.M.; Vázquez, M.J.M.; Hernández, M.M.; Homar, P.S.; Beneitez, J.V.; Gorría, M.J.M.; Fernández-Vega, M.J.A.; González, E.P.; Bobo, M.T.I. Assessment of activity of care of a nutritional support multidisciplinary team in the follow-up of total parenteral nutrition. Nutr. Hosp. 2006, 21, 57-63.

8. Ayres, E.J.; Hoggle, L.B. 2011 Nutrition Informatics Member Survey. J. Acad. Nutr. Diet. 2012, 112, 360-367. [CrossRef]

9. Vanherle, K.; Werkman, A.M.; Baete, E.; Barkmeijer, A.; Kolm, A.; Gast, C.; Ramminger, S.; Höld, E.; Kohlenberg-Müller, K.; Ohlrich-Hahn, S.; et al. Proposed Standard Model and Consistent Terminology for Monitoring and Outcome Evaluation in Different Dietetic Care Settings: Results from the EU—Sponsored IMPECD Project. Clin. Nutr. 2018, 37, 2206-2216. [CrossRef]

10. García, C.G.; Sebastià, N.; Blasco, E.; Soriano, J.M. Dietopro.Com: Una Nueva Herramienta de Gestión Dietoterapéutica Basada En La Tecnología Cloud Computing. Nutr. Hosp. 2014, 30, 678-685. [CrossRef]

11. Martín, I.S.M.; Fernández, M.G.; Yurrita, L.C. Aplicaciones Móviles En Nutrición, Dietética y Hábitos Saludables: Análisis y Consecuencia de Una Tendencia a La Alza. Nutr. Hosp. 2014, 30, 15-24. [CrossRef]

12. Kight, C.E.; Bouche, J.M.; Curry, A.; Frankenfield, D.; Good, K.; Guenter, P.; Murphy, B.; Papoutsakis, C.; Richards, E.B.; Vanek, V.W.; et al. Consensus Recommendations for Optimizing Electronic Health Records for Nutrition Care. Nutr. Clin. Pract. 2020, 35, 12-23. [CrossRef] [PubMed]

13. Cubero, J.; Narciso, D.; Valero, V.; Rodríguez, A.B.; Barriga, C. Características y aplicaciones de software en dietética y nutrición para su uso en poblaciones sanas y pacientes críticos. Enfermería Glob. 2007, 6, 223. [CrossRef]

14. Román, D.D.L.; Guerrero, D.B.; Luna, P.P.G. Dietoterapia, Nutrición Clínica y Metabolismo; Ediciones Díaz de Santos: Madrid, Spain, 2012; ISBN 978-84-9969-293-7.

15. Buchholz, D.; Kolm, A.; Vanherle, K.; Adam, M.; Kohlen-Berg-Müller, K.; Roemeling-Walters, M.; Wewerka-Kreimel, D.; Gast, C.; Lange, K.; Ohlrich-Hahn, S.; et al. Process Models in Dietetic Care A Comparison between Models in Europe. Ernahr. Umsch. 2018, 65, 154-163. [CrossRef]

16. Hammond, M.I.; Myers, E.F.; Trostler, N. Nutrition Care Process and Model: An Academic and Practice Odyssey. J. Acad. Nutr. Diet. 2014, 114, 1893-1894. [CrossRef] [PubMed]

17. EFAD. Nutrition Care Process and Standardised Language. Available online: http://www.efad.org/en-us/professional-practice/ nutrition-care-process-and-standardised-language/ (accessed on 10 November 2020).

18. Carbajal, Á.; Sierra, J.L.; López-Lora, L.; Ruperto, M. Proceso de Atención Nutricional: Elementos para su implementación y uso por los profesionales de la Nutrición y la Dietética. Rev. Esp. Nutr. Hum. Dietética 2020, 24, 172-186. [CrossRef]

19. National Library of Medicine Medical Records-MeSH-NCBI. Available online: https://www.ncbi.nlm.nih.gov/mesh/68008499 (accessed on 28 April 2019).

20. Pablo-Rocano, E. Quality Evaluation of the Records of the Dead Patient's Medical Charts in the Emergency Department of a General Hospital. Rev. Soc. Peru Med. Interna 2008, 21, 51-54.

21. Swan, W.I.; Pertel, D.G.; Hotson, B.; Lloyd, L.; Orrevall, Y.; Trostler, N.; Vivanti, A.; Howarter, K.B.; Papoutsakis, C. Nutrition Care Process (NCP) Update Part 2: Developing and Using the NCP Terminology to Demonstrate Efficacy of Nutrition Care and Related Outcomes. J. Acad. Nutr. Diet. 2019, 119, 840-855. [CrossRef]

22. Herrera, M. Guía de La Asociación Americana de Dietética Para El Cuidado y Manejo Nutricional En Países En Transición Nutricional. An. Venez. Nutr. 2010, 23, 12.

23. Usabilidad. Available online: https://iso25000.com/index.php/normas-iso-25000/iso-25010/23-usabilidad (accessed on 10 November 2020).

24. Huber, M.T.; Highland, J.D.; Krishnamoorthi, V.R.; Tang, J.W.-Y. Utilizing the Electronic Health Record to Improve Advance Care Planning: A Systematic Review. Am. J. Hosp. Palliat. Care 2018, 35, 532-541. [CrossRef]

25. EasyDiet ${ }^{\circledR}$-Programa de Gestión de La Consulta Exclusivo Para Dietistas Nutricionistas. Available online: https://www. easydiet.es / index.php?p=requerimientos_energeticos\&idp=5163 (accessed on 10 November 2020).

26. DietoPro-Software Nutricional Para Dietistas-Nutricionistas. Available online: https://dietopro.com/ (accessed on 10 November 2020).

27. Ruiz, M.N.S.; Fernández, B.M.; Ontoso, I.A.; Guillén-Grima, F.; Monzó, I.S.; Armayor, N.C.; Cantón, J.H.d.M.; Stock, C.; Kraemer, A.; Annan, J. Análisis de La Percepción de La Imagen Corporal Que Tienen Los Estudiantes Universitarios de Navarra. Nutr. Hosp. 2015, 31, 2269-2275. [CrossRef]

28. Ramos, P.; Rivera, F.; Pérez, R.S.; Lara, L.; Moreno, C. Diferencias de Género En La Imagen Corporal y Su Importancia En El Control de Peso. Escr. Psicol. Psychol. Writ. 2016, 9, 42-50. [CrossRef] 
29. Flores, P.J.; Cruz, A.J.; Gascón, M.B. Insatisfacción Con La Imagen Corporal En Niños y Adolescentes: Revisión Sistemática. Nutr. Hosp. 2017, 34, 479-489. [CrossRef] [PubMed]

30. Prieto, I.R.; Fernández, M.S.; Ríos, P.B.; Jáuregui-Lobera, I. Obesidad y Rasgos de Personalidad. Trastor. Conducta Aliment. 2010, 12, 1330-1348.

31. Urdampilleta, A.; López-Grueso, R.; Martínez-Sanz, J.M.; Mielgo-Ayuso, J. Parámetros Bioquímicos Básicos, Hematológicos y Hormonales Para El Control de La Salud y El Estado Nutricional En Los Deportistas. Rev. Esp. Nutr. Hum. Diet. 2014, 18, 155-171. [CrossRef]

32. Urdampilleta, A.; Martínez-Sanz, J.M.; Lopez-Grueso, R.; Lopez-Grueso, R. Valoración Bioquímica Del Entrenamiento: Herramienta Para El Dietista-Nutricionista Deportivo. Rev. Esp. Nutr. Hum. Diet. 2013, 17, 73. [CrossRef]

33. Farias, M.M.; Cuevas, A.; Ducci, H. Más Allá Del Sodio: Cambios En La Dieta y Su Efecto En Hipertensión. Rev. Chil. Cardiol. 2013, 32, 141-151. [CrossRef]

34. Müller, M.J.; Braun, W.; Pourhassan, M.; Geisler, C.; Bosy-Westphal, A. Application of Standards and Models in Body Composition Analysis. Proc. Nutr. Soc. 2016, 75, 181-187. [CrossRef]

35. Armesilla, M.D.C. Compendio de Cineantropometria; CTO MEDICINA: Madrid, Spain, 2009; ISBN 978-84-92523-72-6.

36. Cruz, J.R.A.; Armesilla, M.D.C.; de Lucas, Á.H. Protocolo de valoración de la composición corporal para el reconocimiento médico-deportivo. Documento de Consenso del Grupo Español de Cineantropometría de la Federación Española de Medicina del Deporte. Arch. Med. Deporte Rev. Fed. Esp. Med. Deporte Confed. Iberoam. Med. Deporte 2009, 16, 166-179.

37. Madden, A.M.; Smith, S. Body Composition and Morphological Assessment of Nutritional Status in Adults: A Review of Anthropometric Variables. J. Hum. Nutr. Diet. 2016, 29, 7-25. [CrossRef]

38. Mahan, L.K.; Raymond, J.L. Krause Dietoterapia, 14th ed.; Elsevier: Amsterdam, The Netherlands, 2017; ISBN 978-84-9113-084-0.

39. Ortega, R.M.; Pérez-Rodrigo, C.; López-Sobaler, A.M. Métodos de Evaluación de La Ingesta Actual: Registro o Diario Diétetico. Rev. Esp. Nutr. Comunitaria 2015, 21, 34-41. [CrossRef]

40. Zehnder, B.C. Sodio, Potasio e Hipertensión Arterial. Rev. Méd. Clín. Condes 2010, 21, 508-515. [CrossRef]

41. Kerksick, C.M.; Wilborn, C.D.; Roberts, M.D.; Smith-Ryan, A.; Kleiner, S.M.; Jäger, R.; Collins, R.; Cooke, M.; Davis, J.N.; Galvan, E.; et al. ISSN exercise \& sports nutrition review update: Research \& recommendations. J. Int. Soc. Sports Nutr. 2018, 15, 38. [CrossRef]

42. Aragon, A.A.; Schoenfeld, B.J.; Wildman, R.; Kleiner, S.; Van Dusseldorp, T.; Taylor, L.; Earnest, C.P.; Arciero, P.J.; Wilborn, C.; Kalman, D.S.; et al. International Society of Sports Nutrition Position Stand: Diets and Body Composition. J. Int. Soc. Sports Nutr. 2017, 14, 16. [CrossRef] [PubMed]

43. Ainsworth, B.E.; Haskell, W.L.; Herrmann, S.D.; Meckes, N.; Bassett, D.R.; Tudor-Locke, C.; Greer, J.L.; Vezina, J.; Whitt-Glover, M.C.; Leon, A.S. 2011 Compendium of Physical Activities: A Second Update of Codes and MET Values. Med. Sci. Sports Exerc. 2011, 43, 1575-1581. [CrossRef] [PubMed]

44. Rodríguez, R.F.; Crovetto, M.M.; González, A.A.; Morant, C.N.; Santibáñez, T.F. Consumo de Suplementos Nutricionales En Gimnasios, Perfil Del Consumidor y Características de Su Uso. Rev. Chil. Nutr. 2011, 38, 157-166. [CrossRef]

45. Atkins, M.; Basualdo-Hammond, C.; Hotson, B. Dietitians of Canada Canadian Perspectives on the Nutrition Care Process and International Dietetics and Nutrition Terminology. Can. J. Diet. Pract. Res. 2010, 71, 18-20. [CrossRef]

46. Van Velsen, L.; Beaujean, D.J.; Van Gemert-Pijnen, J.E. Why Mobile Health App Overload Drives Us Crazy, and How to Restore the Sanity. BMC Med. Inform. Decis. Mak. 2013, 13, 23. [CrossRef] 